\title{
Mental Health, Drug Use and Adolescence: Meeting the Needs of Vulnerable Students in Secondary School
}

\author{
Ylva Odenbring ${ }^{1}$
}

Published online: 4 December 2017

(C) The Author(s) 2017. This article is an open access publication

\begin{abstract}
Today, an increasing number of students are suffering from different kinds of mental health problems. Still, we know little about how professionals in secondary school and other professionals in society handle and collaborate around these issues. The findings from the present study make an important contribution to the research field regarding professionals' efforts to meet the needs of vulnerable students. The present study investigates how school professionals in two Swedish urban schools and the local police describe their experiences with meeting the needs of students who are suffering from mental health problems and drug use. The study draws on semi-structured interviews with the professionals and observations of the schools' student welfare team meetings. The findings reveal that self-medication, through use of pills or drugs (or both), has become quite common among adolescents, who see it as a way to 'solve their mental health problems. Although students' wellbeing and school safety were reported to be major concerns, the professionals' collaborations were sometimes obstacles. Issues connected to the complexity of adolescents' mental health not only highlight the importance of collaboration between schools and other societal institutions, but also indicate the necessary resources for such collaboration.
\end{abstract}

Keywords Adolescence · Drug use - Mental health · Urban · Secondary school $\cdot$ Self-medication

Ylva Odenbring

ylva.odenbring@gu.se

1 Department of Education, Communication and Learning, University of Gothenburg, Box 300, 40530 Gothenburg, Sweden 


\section{Introduction}

During recent decades, adolescents' mental health problems have been recognized as a major and increasing problem in schools as well as society at large (Powers et al. 2013; Wiklund and Fjellman-Wiklund 2013). Current tendencies in society show that an increasing number of young people are suffering from different forms of anxiety and have to seek professional support to handle these issues. Research also indicates that good social relations with other peers, parents and other adults are crucial to children's and adolescents' health and well-being - the most vital social relation being that with parents. Besides the importance of having a secure home environment, educational institutions, such as schools, play an important role in terms of supporting students and meeting their welfare needs (Statens folkhälsoinstitut 2013).

In Sweden, school is one of the societal institutions in which young people spend a considerable amount of time. Students in Sweden attend 9 years of compulsory schooling, from grade one to nine, i.e., from the year they turn seven until the year they turn sixteen (SFS 2010:800). This makes the school a central workplace for adolescents, and therefore of great importance to their health and wellbeing as well as general feelings of safety and security. The school is one of the institutions in Swedish society that should ensure all students' health and wellbeing. If a student is suffering from any kind of mental health problem, for instance anxiety, drug addiction or violence in the home environment, it is the school principal's legal responsibility to not only establish parental involvement, but also involve other societal agencies, such as the social services (Skolverket 2011; Socialstyrelsen 2014).

It is against this background the present study aims to investigate how key officials working in the school's student welfare team describe and experience their efforts to support vulnerable students and meet these students' needs. The aim is also to investigate how the local police describe their own efforts to support vulnerable adolescents. More specifically, with respect to vulnerability, the main focus of the study is on how adolescents' mental health and drug use are recognized and categorized by the professionals. Also of interest is to investigate how the school professionals and local police experience their collaboration with each other and with other agencies in society.

The present study is part of an extensive case study of student welfare teams at nine urban secondary schools (enrolling students from 6th to 9th grade) in different urban areas in southern Sweden. These schools were selected due to their location in different demographic and catchment areas. This article draws on data from the two most significant case studies dealing with students' welfare and drug use.

\section{Health, Drugs and Adolescence}

The present research overview will be organized and presented under three main headings illustrating some of the main features found in the research literature. They are as follows: (1) drug use and health problems and (2) maltreatment and (3) school and parental involvement. 


\section{Drug Use and Health Problems}

Research on adolescents' drug and alcohol use has shown that a low level of wellbeing is significantly higher among students who smoke, consume alcohol and use drugs (Hagquist 2006; Kahlin 2013). Peers often play an influential role in adolescents' substance use and recovery from addiction. Research has also shown that a supportive school climate, where students and school officials work together to create a sense of community, leads to positive outcomes for adolescents recovering from substance use (Karakos 2014).

Issues of gender and drug use have also been highlighted in the research literature. The tendency in these studies has been to focus on young men and drug use. Campbell et al.'s (2013) study on service providers' views on vulnerable young men (aged 14-20 years) shows that normative gendered expectations regarding masculinity, stress and emotional isolation increased the risk of excessive drug and alcohol use. Drug and alcohol use often lead to aggressive and violent behaviour. Their study reveals the importance of giving young men the opportunity to talk about their problems. Lalander's (2009) longitudinal study of young adult men with long-term heroin use and addiction reveals that the young men in the study were dreaming of a better life. These young men, all of whom had an immigrant background and had grown up in a disadvantaged neighbourhood, expressed a desire to break the stigma and to live what they referred to as 'a normal life', i.e. have a job, income and be integrated into Swedish society.

\section{Maltreatment}

The research literature on maltreated and abused children indicates that maltreatment has a negative effect on students' mental health (Backett-Milburn and Jackson 2012; Jonson-Reid et al. 2007; Gunnestad 2009). Child abuse is often related to poverty, and poverty frequently increases the risk of alcohol and drug abuse in the family. For this group of children, fear of being removed from their homes and their parents' insistence that they not talk about their problems outside the family result in children seldom reporting their problems to the social services (Hill 2015; Backett-Milburn and Jackson 2012). Instead children often seek support through friends, by talking to them, and sometimes their friends' homes provide a safe place to stay (Hill 2015; Odenbring et al. 2015).

These results are similar to findings from a Norwegian and South African study (Gunnestad 2009). Gunnestad's study shows that the social network is essential for abused children and that the supportive network included not only close friends and grandparents, but also parents. In the South African context, the network was wider than the network in the Norwegian context, because the South African network included church members, pastors and other neighbourhood residents. The results from the Norwegian context also show that the social welfare system failed to provide the necessary support for the abused children. As a result, the abused children were abused for many years or even throughout their childhood. Having someone to trust and turn to and receiving moral and practical support were of vital importance to the children in both countries. 


\section{School and Parental Involvement}

The research literature on school involvement indicates that adolescents exposed to maltreatment in the home often have behavioural problems at school (Jonson-Reid et al. 2007). The school's involvement is crucial in such cases. Still, research conducted in Sweden reveals that, in cases of suspected maltreatment, the schools' collaborations with the social services involve more extended processes (Näsman 2012). In situations where students have been using drugs or are stay-at-home students, the step to filing a report is normally much faster. King and Scott's (2013) study reveals that different professional groups tend to report different things. Teachers more often report cases involving students' physical, emotional, and behavioural problems. In cases of documented and serious maltreatment, teachers were as likely as other professionals to report risk factors associated with the family.

Research on parental involvement in schools indicates that vulnerable students benefit from a good collaboration between the school and the family (Halgunseth and Peterson 2009; Weitz Spånberger 2011). The school's positive relations with parents will have a positive impact on the student's mental health and well-being. Nonetheless, research also indicates that different structures in society might disturb and threaten the trusting relation between parents and the school. Studies have also shown that parents with an immigrant background are often marginalized or even ignored when they try to discuss their children's situation at school. Problems in families with an immigrant background are often discussed and framed in relation to culture and ethnicity, whereas problems in families with a majority background are discussed as social problems (Lunneblad and Johansson 2012; Mattsson 2010).

This overview reveals some of the tendencies in the research field. Yet, we know little about how professionals in secondary schools and the local police collaborate in situations involving vulnerable students and what kind of support they offer these students. The present study hopes to contribute new knowledge concerning how the school and the local police support vulnerable students and meet their needs.

\section{The Study}

The study was designed as a case study of two urban secondary schools located in southern Sweden. By investigating the selected cases, comparing and seeking a deeper understanding of them, the study aims to generate knowledge about complex phenomena, such as the social relations and social structures at the respective schools (Hammersley and Atkinson 2007). For the present study, this means that the empirical analysis starts from an understanding based on a multifaceted social reality, where the informants' narratives on vulnerable students include multiple discourses.

\section{Selected Schools}

Rosehip Hill School is a public school located in a gentrified neighbourhood in Bay City, which is located in one of Sweden's metropolitan areas. A majority of the 
inhabitants in the neighbourhood have an academic degree, but the average income matches the national average. The neighbourhood could be described as a 'mixed', white middle-class area. The majority of students attending Rosehip Hill School have a lower-middle class or middle-class background. Approximately one-fifth of students have an immigrant background, which is below the city's average proportion.

Meadow School is a public school located in Queen's Town-a small town with a population of approximately 20,000. The majority of inhabitants in the municipality where Queen's Town is located have an academic degree, and the average income is above the national average. The municipality could be described as quite wealthy, and the bulk of the population could be categorized as middle class. At Meadow School, the students' backgrounds are relatively mixed in terms of both socioeconomic status and ethnicity. About one-third of students at the school have an immigrant background, which is above the average proportion for other schools in the municipality. The majority of the students with immigrant background have ancestry in the Middle East (Lebanon, Palestine, Iraq, Iran and Syria), East Africa (Ethiopia and Somalia), the Far East (Afghanistan and Pakistan) and the Balkan states.

Access to the schools was gained through the headmasters at the respective schools. Thus, the headmasters were important gatekeepers for the study. Initially I contacted and informed the headmasters about the study though personal e-mails and phone calls. To ensure trustworthiness, I also personally visited the respective schools to meet the headmasters together with the other members of the student welfare teams as well as to inform them about the study and obtain permission to conduct the study (Vetenskapsrådet 2011). Moreover, the local police officer responsible for Meadow school, was initially contacted and informed about the study through personal e-mails and a phone call. To further ensure trustworthiness, I also provided information on the research project at the time of the interview. The police officer also expressed interest in participation in the study.

All informants were also informed about the ethical considerations regarding confidentiality (Vetenskapsrådet 2011). To ensure confidentiality, the names of all informants and schools are pseudonyms. This means that all informants are referred to using generic identifiers, such as "headmaster" or "school nurse". The schools in the present paper have been given the pseudonyms Rosehip Hill School and Meadow School.

\section{Methodology}

To investigate how adolescents' mental health and drug use were recognized and categorized by the professionals and to understand these professionals' efforts to meet the needs of vulnerable students, the combination of conducting interviews with the professionals and making observations of student welfare team meetings was considered the most suitable methodological approach for the present study.

The data collected at the two secondary schools derive from observations of student welfare team meetings as well as from individual and focus group interviews with key officials working in the student welfare teams. The individual 
and focus group interviews were semi-structured. Both observations and interviews were conducted at the respective schools. The key officials working in the student welfare meetings are the headmaster, school nurse, school counsellor, special education teacher and sometimes other school officials. The student welfare team group meets once a week or twice a month to discuss students who need some kind of extra support and to try to find solutions for students who need such support.

This study also includes an interview with the local police chief, who work closely with the key officials at Meadow School. These interview questions were also semi-structured, and the interview was conducted at the local police station. When the school officials suspect drug use or any other kind of criminal behaviour on the part of students, they get in touch with the local police, who then visit the school. The local police visit different schools in the municipality of Queen's Town, one of which is Meadow School.

All interviews were audio-recorded and transcribed on the computer. Individual as well as focus group interviews lasted for approximately an hour. The observations of the student welfare team meetings were documented by handwritten notes and later transcribed on the computer. These meetings lasted from 1 to $2 \mathrm{~h}$. When all of the data had been collected and transcribed, I read through the material multiple times to identify recurrent themes.

Methodologically, the present study is influenced by discourse analysis in a broader sense, but the study also seeks to place the narratives within a sociological framework (Foucault 2001; Wodak and Kryzanowski 2008). Theoretically this study analyses how school officials and the police described and categorized vulnerable students and what kind of support these students were offered (Foucault 2001). According to Foucault, the educational system both allows and prevents certain established policies, which means that existing discourses are either maintained or changed (Foucault 1993). As a result, it also maintains and changes the knowledge and power it possesses. Foucualt (1991, p. 58) talks about three levels of how dependencies of discursive transformations play: (1) Intradiscursive dependencies: the dependencies between the objects, operations and concepts of a single formation; (2) Interdiscursive dependencies: the dependencies between different discursive formations and (3) Extradiscursive dependencies: the dependencies between different discursive formations and transformations outside of discourse, such as social changes in the society.

In the current study, the categories used by the professionals to label individual students, groups or situations derive their meaning from different discourses and play between the discursive formations and transformations. The present study aims at further exploring how the different discourses, which emerged from the professionals' narratives, connect to general societal and cultural discourses on students' drug use, vulnerability and mental health (cf. Foucault 1991). The aim is also to investigate how the professionals' narratives connect to discourses on vulnerable youth, mental health problems and drug use and to the schools' and society's responsibilities for handling these issues. When dealing with situations in which there is suspicion of student drug use, the schools and the police have to involve other agencies, such as the social services. 
The empirical analysis will be presented below. The results will be framed and organized under four headings that illustrate the main themes emerging from the professionals' narratives. They are as follows: (1) The situated context, (2) Mental health, (3) School safety and (4) Collaboration with obstacles.

\section{The Situated Context}

In the school officials' narratives, the demographics of the school constituted one of the central aspects of how they defined and categorized the students' problems. At Rosehip Hill, the situated context and the catchment areas were described as quite mixed with regard to social background. Yet families with a middle-class background are the most predominant in the narratives. The explanation for why students use drugs was also framed in terms of the families' social background and an understanding of parents who have liberal attitudes towards drugs, i.e., who are not worried about their children trying drugs such as cannabis, which is one of the most commonly used drugs among adolescents in Sweden (Statens folkhälsoinstitut 2013).

Counsellor: In this neighbourhood there are both families in society's margins, if you know what I mean, and families where parents have a high academic degree and high incomes. Most families are middle class, many in the cultural sector and people who are very aware. Many parents are quite liberal, which also might have an impact on the students.

YO: In what way?

School nurse: Their views on drugs./.../The thing with drugs and things like that is that many think it's alright to try, no one has died by only trying, you hear things like that (Focus group interview, Rosehip Hill School).

Similar to Rosehip Hill School, Meadow School's catchment area was also categorized as mixed by the school officials working there. However, the situated context was described and categorized on the basis of other criteria. Although the neighbourhood was categorized as quite mixed, the school officials also claimed that the school sometimes has problems similar those found in schools in the most disadvantaged neighbourhoods in Sweden's major cities, i.e. low educational level, students who need extra support and child poverty.

Special education teacher: The catchment area is quite mixed, but sometimes you get the impression that this is a school in a socially disadvantaged area in one of Sweden's greater cities, even. We have similar problems if you take it to the extreme. We have many students who are growing up in families with low educational level and no study experience. The students' parents can't help them with their homework, that's the way I would describe this school and the catchment area (Individual interview with special education teacher, Meadow School).

Gender was also mentioned in the professionals' narratives. Yet when discussing different social dimensions of students' drug use, family background stands out more clearly than gender does in the school officials' narratives. 
School assistant: Last year it was probably more boys than girls. Then you have the students' social background, it is more common for students from dysfunctional families to use drugs, but there are also students from families with a good financial situation and where you get the impression that everything is fine, who try drugs (Individual interview with school assistant, Meadow School).

On the one hand, students from socially disadvantaged families were mentioned in the narratives; on the other, students from middle-class families with a strong cultural capital were mentioned in the school officials' narratives. The explanation given for students' drug use and their problems is based on a discourse of family background, i.e. the family is either categorized as dysfunctional or liberal on drugs. This discourse is framed in relation to the professionals' understanding of the family situation or the parents' attitudes towards drugs (cf. Foucault 1991).

\section{Mental Health}

Another discourse that framed the school officials' narratives about students' drug habits and drug problems draws on a discourse connected to students' mental health (cf. Foucault 1991). Violence and maltreatment in the home environment was also one of the explanations given for students' mental health problems and drug use.

School assistant: We had this student that we knew was using drugs. This student was almost suicidal, and had almost given up. He showed a video on the mobile phone and it showed how a parent was abusing him. Together with a colleague I immediately contacted the school counsellor and sent a report to the social services. I was so upset that you hardly could talk to me. It was a long story, we filed a report and the student refused to go home. The story about this student goes way back and the social services knew about this student's case very well. The student had given up and cried: "I can't take it anymore, I can't take it anymore, I can't live like this!" Besides filing the report, I also called the social services and talked to them, but they said they couldn't do anything. Apparently, the student has to commit suicide before something happens! That's so wrong, no one should live like that, you can't really say that, I told the social services. But that's the way it was (Individual interview with school assistant, Meadow School).

The school assistant expressed frustration about how the social services handled the case. Despite her efforts to help the vulnerable student, according to her the social services did nothing. These results correspond with previous research. School officials often express their disappointment with the social services' work and with the extended and slow investigations (Odenbring et al. 2015).

Another aspect revealed in the school officials' narratives was that their narratives on family violence were framed around the notion of the dysfunctional family. Students in such home environments were described as lacking proper role models, among either family members or friends. According to the school officials 
in the present study, the school is the only safe place for this group of vulnerable students. The results also reveal that these students were struggling with their drug problems and desired professional help. For example, one of the students discussed by the student welfare team at Meadow School was a girl named Amy (aged 12) who was attending the sixth grade.

Counsellor: Today Amy and her mother visited the special education group. Amy doesn't want to attend that group. She was wondering if she is attending "the retarded group" now.

Headmaster: So did she attend this meeting?

Counsellor: Yeah, she did, but when I talked to her she couldn't remember what they had talked about. Amy and her mother had a fight this morning/.../. Special education teacher: What role models does she have, really? What will stop her from using drugs? She has no good friends or good family members.

Headmaster: The school is the only safe place for her. The results from the drug test [the urine test] she took were positive. Amy has also smoked cannabis and there will be a meeting with the social services tomorrow.

Special education teacher: Amy has told me that she wants to be clean and she has expressed that "it's not enough to just take a piss test".

Counsellor: Well, that is very insightful of her (Field notes, student welfare team meeting, Meadow School).

The discourse about the students' mental health not only revealed concerned and worried school officials, the results also showed that students who were suffering from different forms of mental health problems tried to find their own solutions to the problems. This was also something the local police had recognized. The local police had experienced adolescents self-medicating and even mixing drugs with anti-depressants, thus creating a 'cocktail' of substances in their bodies.

Local police: I've met many young people who've started smoking cannabis who think it's harmful, and then after a while you can see that they are depressed, have problems sleeping and then they go to the doctor with their parents and the doctor prescribes anti-depressants or sleeping pills and that's when they're introduced to Benzodiazepines./.../. That is often the case. In the long run, this will also have an impact on adolescents' mental health. They're happy and they're not coping with school because of their mental health problems (Individual interview with the local police).

The discourse around students' mental health also reveals an increased number of students suffering from different forms of anxiety (cf. Foucault 1991). According to the school officials and local police, this has resulted in an increasing number of students who try to relieve their anxiety through self-medication. These results are similar to a national survey on children's and adolescents' health showing a strong correlation between cannabis use and mental health problems (Statens folkhälsoinstitut 2013). Cannabis users also report a high level of worry, nervousness and anxiety. This group use anti-depressants to a greater extent, have a higher rate of suicide or of suicide attempts compared to other same-age groups. There is also a 
general tendency in Swedish society towards increasing stress and anxiety among young people, particularly girls and young women. As a result, the medical precriptions and use of anti-depressants have increased (Socialstyrelsen 2017).

\section{School Safety}

The school officials' narratives regarding students' drug use and addiction were also framed around a school safety discourse. One of the aspects that framed the school safety discourse was connected to student safety. The special education teacher at Meadow School reported experiencing school safety problems several times during his years working at the school.

Special education teacher: I have experienced when we've closed down classes because we have suspected that students were addicted.

YO: What happened then?

Special education teacher: Well, we recognized that several of the students were addicted and it didn't feel safe in the classroom. I have experienced this at several schools I've worked at.

YO: Have you also experienced that here at Meadow School?

Special education teacher: Definitely.

YO: Can you tell me a little bit more about these kinds of situations? Were the students addicted to drugs and how did they react and behave in the classroom?

Special education teacher: We compared their normal behaviour and noticed that they were behaving differently. We were two teachers in the classroom at that time and the other teacher and I noticed that we couldn't reach several of the students. We didn't directly look of the size of theirs' apple of the eye, but something was wrong, that was for sure. It was several minor things that made it so hard to discover, it's like small incidents all the time.

YO: How old were the students?

Special education teacher: They were in the ninth grade. We handed over the case to the principal and the student welfare team and then the principal filed a report to the police (Individual interview with special education teacher, Meadow School).

To ensure all students' safety, the class was closed down. The case was then handed to and taken over by the principal, and the students' welfare team and the principal filed a report to the police. As part of the school's routines, the school principal at Meadow School always filed a report to the police and involved the police in further investigating the case.

Students addicted to drugs were also sometimes a concern for the safety of the professionals. This was raised, for instance, by the school nurse at Rosehip Hill School during a student welfare team meeting. During this meeting the key officials discussed a girl named Filippa. According to the school officials, she was using drugs and was addicted to them. Her family situation was also described as problematic, because she and her father had a difficult relationship. Because of 
Filippa's vulnerable situation and her mental health problems, the school had filed a report to the child and youth psychiatric care clinic, which means that psychiatric care was also involved in the case. At the student welfare meeting, the school nurse described an occasion when she was concerned about Filippa's health and wellbeing and wanted to help her: Filippa was sleeping outside on the school campus.

School nurse: Filippa is acting very rowdy. I watched her sleeping outside and she had earphones in her ears. I walked to her and called her name several times, but she didn't respond, so I tried to wake her up. She roused awakened and got up and her eyes were totally dark and she yelled: "You touched me really hard! You are hurting me!" There were no other adults around so I thought that she might harm herself and then blame me for it (Field notes, student welfare team meeting, Rosehip Hill School).

The students' drug addiction and unpredictable behaviour caused several concerns about school safety. The school safety discourse was not only framed based on concerns about students' safety and wellbeing, it also included concerns about the professionals' safety and wellbeing. The school nurse at Rosehip Hill also raised another dimension of school safety, which is the fear of being falsely accused of abusing students. What we might be seeing here is a result of the legalization of the school system in Sweden. Contemporary research shows that school professionals are experiencing an increased tendency among students and their parents towards accusing school professionals of offending students (Hult and Lindgren 2016). Schools in Sweden have also experienced an increased number of police reports filed by students and their parents. According to the school professionals, this creates a sense of uncertainty and a feeling of entering into a 'minefield', because they never know who will be reported and when.

\section{Collaboration with Obstacles}

Meeting the needs of vulnerable students also involved having insights into the students' lives outside school. As for the police, when they were patrolling the streets of Queen's Town they encountered adolescents who were using drugs and involved in various criminal activities. According to the police, it is quite often the same group of adolescents they have observed drifting around town whom they later encounter during collaborations with the school professionals and during school visits.

Local police: The principal at Meadow School calls us and tells us about his concern about students who are behaving strangely. We then drive over there and talk to the student concerned. If we suspect that the individual is addicted to narcotics we do a body check, i.e. a urine test on that person. Then we make a quick test of the urine sample and it either indicates negative or positive. After that we send the sample in for a complete laboratory test to The National Board of Forensic Medicine. When we receive the results [i.e., the result shows positive] from this test we call the student and guardians for 
questioning, and then we file a report to the social services. After that it is the social services' responsibility to offer the student the necessary support and treatment (Individual interview with the local police).

It is the school principal who calls the police when the school professionals suspect that students have been taking drugs or that drug dealing has been taking place at the school. Although both the school officials and the local police experienced and referred to their professional relations as good, the local police also expressed frustration about the lack of resources available to do a proper job and to make the necessary school visits to help and support this group of vulnerable students.

Local police: Last semester when we received a report from the principal we drove over there and made a school check and body searched students [for narcotics]. But we are not only supposed to body search the students, we are also there to get to know the students in their school environment, but we are not quite there yet, right now we only have the resources to "put out the most urgent fires", so to speak (Individual interview with the local police).

The narratives of the police and school officials also reveal a discourse connected to organization - a collaboration with obstacles - i.e., organizational challenges and organizational problems from a general and wider perspective (Foucualt 1991). Although the school officials and the police referred to their professional relations and collaboration in positive terms, their collaboration was challenged by the lack of police resources. As mentioned earlier, the school officials' narratives were framed by frustration with the social services and the challenges connected to that collaboration. The discourse connected to organization involved challenges and made it difficult for the school and the police to collaborate with other authorities to the extent they desired. In the long run, this will most likely have an impact on the kind of support students are offered.

\section{Discussion}

The aim of the current study was to investigate how key officials working in the school's student welfare team and the local police described their efforts to meet the needs of vulnerable students, i.e. students with drug and mental health problems. The empirical analysis and results reveal four main themes connected to the study aim: (1) the situated context, (2) mental health. (3) school safety and (4) collaboration with obstacles. The empirical results show that students' drug use and mental health problems are often closely connected.

Two main explanations connected to students' drug use and addiction framed the school officials' narratives. The picture that emerge and the explanation given regarding students' drug use concerned either the image of a family with liberal attitudes towards drugs, i.e. the middle-class family, or the dysfunctional family, i.e. the socially disadvantaged family. Despite the fact that the narratives are framed 
around a discourse connected to family background as well as aspects of social class, the empirical analysis does not reveal a clear-cut class perspective.

Another discourse that strongly framed the officials' narratives and the explanations given for students' drug use was one connected to students' mental health problems. This discourse was not only predominant in the school officials' narratives concerning students' drug problems, but also in the local police's narratives. Violence and maltreatment in the home environment were given as one of the main explanations for students' mental health problems and drug use. These results correspond with findings from previous studies indicating that maltreatment and child abuse have a great impact on students' health and wellbeing (BackettMilburn and Jackson 2012; Jonson-Reid et al. 2007; Gunnestad 2009).

Although the officials in the current study expressed great concern about the students' health and wellbeing, collaboration with the social services was experienced as a major dilemma. The narratives concerning collaboration with the social services were framed in relation to a discourse on organization. According to the school officials, it is the routines at the social services office that cause these problems, and from the school officials' point of view, this is what leads to their collaboration difficulties. Also the police's lack of resources was framed around a discourse connected to organization-yet these narratives related to the police force's difficult financial situation and experiences with this dilemma. The present results on the school officials' disappointment regarding collaboration with the social services correspond with findings from previous studies (Odenbring et al. 2015). Still, previous studies also indicate that cases of maltreatment more often involve long and extended processes before the school actually files a report to the social services (Näsman 2012). In addition, previous studies have shown that the step to filing a report is often much faster in cases of students' drug use or stay-athome students.

School safety was the fourth discourse that framed the narratives. The school safety discourse in the current study is not connected to guns or weapons, as shown in previous studies (Ellis et al. 2015). Instead the present results are connected to a school safety discourse where drug addict students' unpredictable behaviour had an impact on school safety. This discourse revealed two dimensions of school safety: (1) the safety of students and (2) the safety of the teachers as well as teachers' fear of being falsely accused and reported by students and their parents.

The present study is based on two case studies, which naturally entails limitations with regard to making general conclusions about how school officials, together with the local police, deal with student welfare and drug use issues. Nevertheless, the results do say something about general societal tendencies related to adolescents' mental health problems. The study has explored the views of school professionals and the local police on issues regarding meeting the needs of vulnerable students, which constitutes an important methodological contribution to the research field. The findings are also important with regard to creating a broader and deeper understanding of students' health issues and of how professionals deal with and experience their collaboration around these issues. The study raises questions concerning future research on students' experiences of and views on their mental health and wellbeing - an area that is still relatively unexplored. 
To conclude, an increasing number of adolescents are suffering from mental health problems today (cf. Gecková et al. 2003; Giota and Gustafsson 2016; Wiklund and Wiklund-Fjellman 2013; Wiklund et al. 2012). Findings from the current study reveal that it has become more common for young people to selfmedicate, by using drugs and pills to 'handle' their problems, regardless of whether these problems are related to domestic violence or something else. This raises questions about society's responsibility for meeting the needs of vulnerable students and the importance of giving all involved agencies the necessary tools and resources to do so. It also stresses the importance of good inter-agency collaboration in meeting these needs.

Open Access This article is distributed under the terms of the Creative Commons Attribution 4.0 International License (http://creativecommons.org/licenses/by/4.0/), which permits unrestricted use, distribution, and reproduction in any medium, provided you give appropriate credit to the original author(s) and the source, provide a link to the Creative Commons license, and indicate if changes were made.

\section{References}

Backett-Milburn, K., \& Jackson, S. (2012). Children's concerns about their parents' health and wellbeing: Researching with ChildLine Scotland. Children and Society, 26, 381-393. https://doi.org/10. 1111/j.1099-0860.2010.00349.x.

Campbell, J., Rondon, J., Galway, K., \& Leavey, G. (2013). Meeting the needs of vulnerable young men: A study of service provider views. Children and Society, 27, 60-71. https://doi.org/10.1111/j.10990860.20111.00372x.

Ellis, J. M., Rowley, L. L., Nellum, C. J., \& Smith, C. D. (2015). From alienation to efficacy. An examination of racial identity and racial academic stereotypes among black male adolescents. Urban Education. https://doi.org/10.1177/0042085915602538.

Foucault, M. (1991). The Foucualt effect. Studies in governmentality with two lectures by and an interview with Michel Foucault. Chicago: The University of Chicago Press.

Foucault, M. (1993). Diskursens ordning (The order of the discourse) (Original published in 1971). Stockholm: Brutus Östlings Förlag Symposium.

Foucault, M. (2001). The archaeology of knowledge. (original published in 1969). London: Routledge.

Gecková, A., Van Dijk, J. P., Stewart, R., Groothoff, J. W., \& Post, D. (2003). Influence of social support on health among gender and socio-economic group adolescence. European Journal of Public Health, 13, 44-50.

Giota, J., \& Gustafsson, J. E. (2016). Perceived demands of schooling, stress and mental health: Changes from grade 6 to grade 9 as a function of gender and cognitive ability. Stress and Health, 33(3), 253-266.

Gunnestad, A. (2009). International perspectives on child abuse and resilience. Nordic Studies in Education, 30, 18-30.

Hagquist, C. (2006). Health inequalities among adolescents-The impact of academic orientation and parents education. European Journal of Public Health, 17(1), 21-26.

Halgunseth, L. C., \& Peterson, A. (2009). Family engagement, diverse families, and early childhood education programs: An integrated review of the literature. Young Children, 64, 56-58.

Hammersley, M., \& Atkinson, P. (2007). Ethnography. Principles in practice (3rd ed.). London: Routledge.

Hill, L. (2015). 'Don't make us talk!': Listening to and learning from children and young people living with parental alcohol problems. Children and Society, 29, 344-354. https://doi.org/10.1111/chso. 12064.

Hult, A., \& Lindgren, J. (2016). Med lagen som rättesnöre-kunskapsformer i lärares arbete mot kränkande behandling. Utbildning och Demokrati, 25(1), 73-93. 
Jonson-Reid, M., Jiyoung, K., Barolak, M., Citerman, B., Laudel, C., Essma, A., et al. (2007). Maltreated children in schools: The interface of school social work and child welfare. Children and Schools, 29(3), 182-191. https://doi.org/10.1093/cs/29.3.182.

Kahlin, Y. (2013). Physical activity and self-related health in Swedish high school students. Växjö: Linneaus University Press.

Karakos, H. L. (2014). Positive peer support and negative influence? The role of peers among adolescents in recovery high schools. Peabody Journal of Education, 89, 214-228.

King, C. B., \& Scott, K. L. (2013). Why are suspected cases of child maltreatment referred by educators so often unsubstantiated? Child Abuse and Neglect, 38(1), 1-10. https://doi.org/10.1016/j.chiabu. 2013.06.002.

Lalander, P. (2009). Respekt-Gatukultur, ny etnicitet och droger (Respect-Street culture, new ethnicity and drugs). Malmö: Liber.

Lunneblad, J., \& Johansson, T. (2012). Learning from each other? Multicultural pedagogy, parental education and governance. Race Ethnicity and Education, 15(5), 705-723.

Mattsson, T. (2010). Intersektionalitet $i$ socialt arbete. Teori, reflektion och praxis (Intersectionality in social work. Theory, reflection and praxis). Malmö: Gleerups.

Näsman, E. (2012). Barnfattigdom-Om bemötande och metoder ur ett barnperspektiv (Child povertyTreatment and methods from a child's perspective). Stockholm: Gothia Förlag.

Odenbring, Y., Johansson, T., Lunneblad, J., \& Hammarén, N. (2015). Youth victimization, school and family support: Schools' strategies to handle abused children. Education Inquiry, 6(2), 191-207. https://doi.org/10.3402/edui.v6.26417.

Powers, J. D., Edwards, J. D., Blackman, K. F., \& Wegmann, K. M. (2013). Key elements of a successful multi-system collaboration for school-based mental health: In-depth interviews with district and agency administrators. The Urban Review, 45(5), 651-670. https://doi.org/10.1007/s11256-0131239-4.

SFS 2010:800. Skollagen (Education Act). Utbildningsdepartementet: Stockholm.

Skolverket (National Agency for Education). (2011). Läroplan för grundskolan, förskoleklassen och fritidshemmet 2011 (Curriculum for the compulsory school, preschool class and the recreation centre, 2011). Stockholm: Skolverket.

Socialstyrelsen (National Institute of Public Health). (2014). Anmälan till socialnämnden vid kännedom eller misstanke om att ett barn far illa (Reports to the social services in cases of knowledge or suspicion that a child is being abused). Stockholm: Socialstyrelsen.

Socialstyrelsen (National Institute of Public Health) (2017). Hälsan allt bättre-Men ångest och oro ökar (Health is better-But anxiety and nervousness are increasing). http://www.socialstyrelsen.se/ nyheter/2017/halsanalltbattre-menangestochorookar. Accessed 25 April 2017.

Statens folkhälsoinstitut (National Institute of Public Health). (2013). Barn och unga 2013-Utvecklingen av faktorer som påverkar hälsan och genomförda åtgärder (Children and young 2013-The development of factors that have an impact on health and measures taken). Östersund: Statens folkhälsoinstiut.

Vetenskapsrådet (The Swedish Research Council). (2011). God forskningssed (Good research practice). Stockholm: Vetenskapsrådet.

Weitz Spånberger, Y. (2011). Ungas erfarenheter av skola, samhällsvård och vuxenblivande: en studie av fem livsberättelser (Young people's experiences of school, out-of-home care and transitions to adulthood: A study of five life stories). Dissertation. Stockholm: Stockholms universitet.

Wiklund, M., \& Fjellman-Wiklund, A. (2013). Stress hos unga-Samband med ångest, hälsobesvär och genus (Stress among youth-Associations with anxiety, mental health issues and gender). Best Practice-Psykiatri/Neurologi. Yrkesdialog mellan specialister, 4(14), 7-11.

Wiklund, M., Malmgren-Olsson, E., Öhman, A., Bergström, E., \& Fjellman-Wiklund, A. (2012). Subjective health complaints in older adolescents are related to perceived stress, anxiety and gender-A cross-sectional school study in Northern Sweden. BMC Public Health, 2012(12), 993.

Wodak, R., \& Krzyzanowski, M. (2008). Qualitative discourse analysis in the social sciences. New York: Palgrave Macmillan. 